\title{
RESEARCH ARTICLE \\ MODELLING SURFACE RUN-OFF RESPONSE USING HYDROLOGICAL MODEL SWAT IN THE UPPER WATERSHED OF RIVER SUBARNAREKHA, INDIA
}

\author{
Pipas Kumar' ${ }^{1}$, Varun Joshi' ${ }^{2}$ \\ ${ }^{1}$ Research Scholar, University School of Environment Management, Guru Gobind Singh Indraprastha University, New Delhi, India. \\ ${ }^{2}$ Professor, University School of Environment Management, Guru Gobind Singh Indraprastha University, New Delhi, India. \\ *Corresponding author Email: pipasx2@gmail.com, varunj63@gmail.com
}

This is an open access article distributed under the Creative Commons Attribution License, which permits unrestricted use, distribution, and reproduction in any medium, provided the original work is properly cited.

\section{ARTICLE DETAILS}

\section{Article History:}

Received 15 August 2019

Accepted 17 September 201

Available online 18 October 2019

\section{ABSTRACT}

Climate change is believed to affect the hydrological pattern of a watershed. The current paper evaluates the ability of a hydrological model Soil and Water assessment Tool (SWAT) to create a scenario of precipitation on the upper watershed of River Subarnarekha, Ranchi, in the state of Jharkhand, India. Sequential uncertainty fitting (SUFI-2) algorithm has been applied for model calibration and uncertainty analysis. The sensitivity analysis was made using a built-in SWAT sensitivity analysis tool that uses the Latin Hypercube One-factor-At-a-Time. The model parameters were calibrated (2001-2005) and validated (2013-2017) with discharge data obtained from CWC hydrological observatory site, Muri (Ranchi). In this study, IPCC SRES A1B Scenario, PRECIS RCM for time slices, near century (2011-2040, or 2020s), mid century (2041-2070, or 2050s) and end century (2071-2098, or 2080s) extracted by Indian Institute of Tropical Meteorology, Pune (India) have been used for the study The analysis shows that the mean annual rainfall will slightly decrease by $19.4 \mathrm{~mm}(1.4 \%)$ in the $2020 \mathrm{~s}$, increase by $86.2 \mathrm{~mm}(6.2 \%)$ in the 2050 s, and further increase by $126 \mathrm{~mm}$ (9.1\%) in the 2080s. For the 2020s, surface runoff shows an average annual decrease by $18.4 \%$. For the 2050 s and 2080 s, there is an average annual increase by $11.8 \%$ and $38.2 \%$ respectively. It may be concluded that the precipitation pattern of the climate projections has a significant impact on water balance components. This study will be useful to take timely decisions for the best possible options to mitigate the impact of climate change.

\section{KEYWORDS}

SWAT, Climate change, Subarnarekha, Hydrologic model, Watershed, Jharkhand, Ranchi.

\begin{abstract}
1. INTRODUCTION
Water is a vital natural resource for agriculture, industry and economic development of a nation. The spatial distribution of water in relation to the population need is uneven [1]. In perspective of rapid urbanization and population growth, this resource is under stress [2]. The sustainable utilization of the water resources is the need of this hour. Thus, proper management of water resources is essential which determine our ability to grow and prosper [3]. Water management issues must be analyzed and quantified using different elements of hydrologic processes taking place within river watershed. The river basin watershed is comprised of many hydrological components (e.g. precipitation, floodplains, watershed, lakes, surface flow, sub-surface flow, seepage, etc.) that work with interdependencies, and gives an approach to river basin development and management [4].
\end{abstract}

The impact of climate change on water resources have been documented by the third assessment report of the Intergovernmental Panel on Climate Change (IPCC). Reports suggested that the average global surface temperature has risen by $0.45^{\circ} \mathrm{C}-0.6^{\circ} \mathrm{C}\left(0.8^{\circ} \mathrm{F}-1.0^{\circ} \mathrm{F}\right)$ and the average sea level has risen approximately $15-20 \mathrm{~cm}$ during the last century. Global Climate Models' (GCMs) projections for the future climate, suggest that the temperature in $20^{\text {th }}$ century have been expected to be between $1.1^{\circ} \mathrm{C}$ and $6.4^{\circ} \mathrm{C}$ higher than temperatures in $19^{\text {th }}$ century [5]. Reports also indicate that the mean annual global surface temperature has increased since the late $19^{\text {th }}$ century and it is anticipated to further increase by $1{ }^{\circ} \mathrm{C}-3.5^{\circ} \mathrm{C}$ over the next 100 years [5]. According to IPCC (2007), fourth assessment report, the average annual precipitation is also expected to increase globally through the end of the century, but there is variation in the amount and intensity of precipitation on regional level.

In this study, a widely accepted hydrological model SWAT [6] has been applied to simulate the effect precipitation on the upper watershed of
River Subarnarekha (UWRS). The hydrological parameter used to simulate the effect of precipitation is surface runoff. SWAT is a physicallybased, a spatially distributed and continuous time watershed model developed to predict the impact of land management practices on water sediment and agricultural chemical yields in large complex watersheds with varying soils, land use and management conditions over long periods of time [6]. The main objective of the study is to investigate the sensitivity of upper watershed of river Subarnarekha in the state of Jharkhand, India for its hydrologic behavior to potential changes in climate variability. The integrated approach of watershed modeling through a hydrological model SWAT has been used. In recent times, several studies have been carried out at various spatial scales, which investigate the hydrological behaviour and response of watersheds arising out of anticipated climate change across the globe at various spatial scales [7-13].

Hydrological models coupled with climate scenarios generated from various climate models can be used to study climate change effects on water resources. In Indian context, since 2002, SWAT model have been applied on numerous watersheds and has become a powerful watershed management tool. In recent years, the integration of remote sensing and GIS techniques has improved the performance and efficiency of SWAT model. India's large population, agrarian economy and long coastline, make it 'considerably vulnerable' to the impacts of climate change. Its large population depends upon climate-sensitive sectors like agriculture and forestry for its livelihood. Any adverse impact on water availability due to recession of glaciers, decrease in rainfall and increased flooding in certain pockets would threaten food security, cause dieback of natural ecosystems and adversely impact the coastal system due to sea-level rise and increased extreme events [14]. India also has witnessed the increasing temperature trends of $0.60^{\circ} \mathrm{C}$ during last 112 years [15]. There is also an increase in heavy rainfall events and decrease in low and medium rainfall events over [16]. 
The sea level rise of approximately one centimetre per decade has been recorded along the Indian coast and there are concerns that global warming may lead to an increase in extreme weather events, such as cyclones and extreme rainfall [17]. Disturbing trends have been witnessed in precipitation, minimum and maximum temperature that presents an alarming situation for the country. There has been suggestion that global warming may influence monsoon dynamics [18]. In a country, where $60 \%$ of farmland is rain-fed, a shift in the rainfall distribution due to climate change would have far-reaching implications for the agriculture-based population [19]. Owing to the current situation of precipitation and rainfall dynamics, it is utmost important to evaluate the possible future trend of weather events. The results obtained in this study are expected to provide precipitation projection with surface runoff variability in different timeline. Thus, hydrological modelling study with SWAT will help in development of scenario which will help in effective and efficient water management of watershed.

\section{MATERIALS AND METHODS}

\subsection{Study area}

The Subarnarekha River is an important catchment of the Eastern region of India. It originates from a small rivulet in the hills of the village name Piskanagri, almost $15 \mathrm{~km}$ from the Ranchi city and passes through undulating landform of plateau three district of Jharkhand, Ranchi, East Singhbhum, and Saraikela Kharsawa, one district of West Bengal, i.e, West Medniapore and finally it joins bay of Bengal near Talsari, Odisha. The river catchment is also characterized by numerous rains fed streams, steep slopes, waterfalls and natural water springs. River Subarnarekha flows for a total length of the study area is predominately called as "Chhotanagpur" plateau. The plateau region lying in the basin is hilly and well forested which is characterized by numerous small streams and isolated hillocks. The soils of Subarnarekha basin are mainly categorized in three groups, the loamy soil, the red gravelly soil, and the lateritic soil. The basin has red soil mostly of residual and alluvial origin and derived from old bedrocks.

The Subarnarekha is spring fed river and water availability depends on monsoon rainfall. According to Köppen Climate Classification, this area is classified as "Humid Subtropical". The summer is hot and starts from the month of March and ends up to June, where as the winter is cold which starts from the month of November and ends up to February. This basin receives its rainfall from the South-West monsoon, which starts from July and ends in October. The average annual rainfall in the basin is around $1400 \mathrm{~mm}$ [20]. The average monthly temperature is $38^{\circ} \mathrm{C}$ in the month of May and $9^{\circ} \mathrm{C}$ in December. Annual mean maximum and minimum temperature varies from $27^{\circ} \mathrm{C}$ to $18.0^{\circ} \mathrm{C}$ respectively. Agriculture is the most important economic activity of the region. The forested vegetation comprises of mainly deciduous and tropical moist forest. The agricultural land is mostly rain fed. Paddy and maize plantation dominate in monsoon season while wheat, mustard, groundnut and some seasonal vegetables in the winter season.

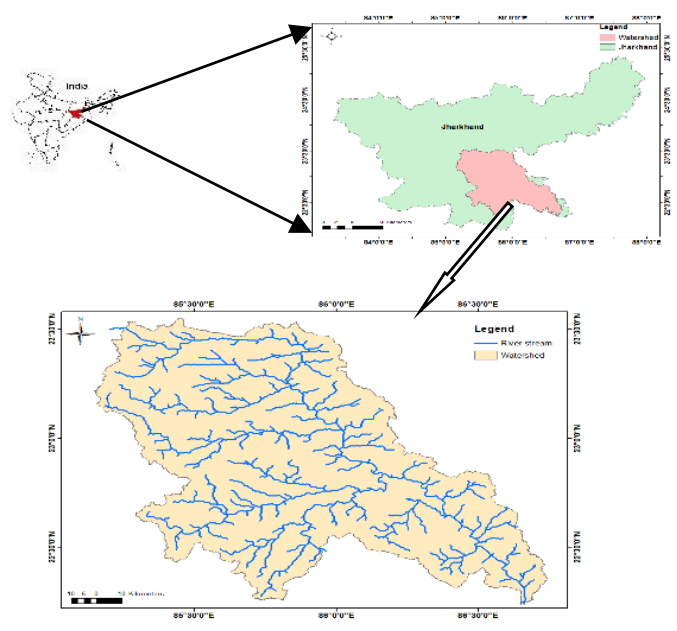

Figure 1: Location of upper watershed of River Subarnarekha in state Jharkhand

\subsection{Description of SWAT model}

SWAT, a hydrological model is a continuous time-series model that can be executed even on a daily time steps [9]. It is capable of routing mechanism on surface runoff, discharge and nutrients of the watershed channels [21]. SWAT model was developed by Agricultural Research Services of United States Department of Agriculture to predict the impact of land management practices on water, sediment, and agriculture chemical yields in large and complex watersheds with varying soil, land use, and management conditions over long periods of time [6]. The Spatial data used as a pre-processing input for the model are Digital Elevation Model (DEM), soil and land use. The DEM defines the topography of the area is used to calculate sub-basin parameters such as slope and to define the stream network [22]. The soil data are required to define soil characteristics and attributes. The land-cover data provide vegetation information on ground and their ecological processes in lands and soils. The model replicates the water balance components of the catchment environment using water balance equation, which considers the unsaturated zone and shallow aquifer above the impermeable layer as a unit [23]. The Soil Conservation Service (SCS) curve number method is used to estimate the of surface runoff that is based on the soil physical properties, land use and hydrological conditions of the watershed [24].

\subsection{SWAT input database}

The watershed simulation study using SWAT requires a large amount of spatial and time series datasets in order to establish the water balance component. The input parameter required for SWAT model are Digital Elevation Model (DEM), land use, river network, soil layer and weather data. These major input data sets and desired map layers of the study area are digitized in GIS environment.

\subsection{Digital Elevation Model (DEM)}

The digital elevation data at a resolution of 90-m acquired through the Shuttle Radar Topography Mission (SRTM) of USGS was processed for the extraction drainage pattern, stream flow direction, flow accumulation, and delineation of the basin and sub-basins [25]. The topographic features such as terrain slope, channel slope or reach length were also established from the elevation data. The elevation output, which shows the minimum and maximum elevation, 48 meter and 1043 meter respectively (Figure 2a) [26].

\subsection{Land use}

The land use changes are an integral component of a watershed that is a function of the density of plant cover and other morphological changes within the catchment [27]. The land use map of the study area digitized in GIS environment. The satellite image is downloaded from http://www.landsat.org and used for the preparation of land use/ land cover layer. The user manual on "National Land Use Land Cover Mapping using multi-temporal satellite data" have been used to define different land use class. Reclassification of the land use map was necessary to assign respective model parameters that were selected from SWAT database. The classified land use map of the watershed is given in figure $2 \mathrm{~b}$. The land use classes of the study area are agricultural land (33.68\%) forested area with deciduous trees $(23.68 \%)$ and water bodies $(16.24 \%)$. The urban settlement and scrub / waster land accounts for $18.54 \%$ and $7.86 \%$ respectively.

\subsection{Soil map}

The Food and Agricultural Organization (FAO) soil map with its soil data properties was used to extract the soil map [28]. However, the soil series map at 1:250,000 scales for Jharkhand state, published by National Bureau of Soil Survey and Land Use Planning (NBSS \& LUP) is used as the source of soil database and soil grid (Figure 2c).

\subsection{Climate dataset}

The runoff response of a river basin is largely dependent upon climatic data (temperature and precipitation). The climate data provides the necessary moisture and energy inputs that control the water balance equation of the watershed [29]. Weather data as an input required for the SWAT model are precipitation $(\mathrm{mm})$, maximum and minimum temperature $\left({ }^{\circ} \mathrm{C}\right)$, relative humidity $(\%)$, solar radiation (hours) and wind speed $(\mathrm{km} / \mathrm{h})$. Observed climate data (Historic- 1969-2012) for nine rainfall stations of the study area were obtained from the India Meteorological Department (IMD), Pune. For SWAT model, the records of precipitation and temperature are the mandatory inputs required for the simulation study [30].

In the study area, four Central Water Commission (CWC) gauging sites (Figure 2d) used to record four different types of data, i.e., gauge, discharge, sedimentation and water quality Ghatshila, Jamshedpur and Adityapur site used to collect all four types of data [31]. The climate datasets for each of precipitation and temperature file were processed as per the Microsoft Access 2003code which is required by the model. Further, Projected weather data of Hadley Centre for Climate prediction at 
U.K. using PRECIS RCM for IPCC A1B scenarios have been used. The PRECIS RCM data has resolution of $0.44^{\circ} \times 0.44^{\circ}$, latitude by longitude grid points. Apart from the baseline, the future time slices selected for the present study are near century (2011-2040, or 2020s), mid century (2041-2070, or 2050s), and end century (2071-2098, or 2080s).



(a)



(c)

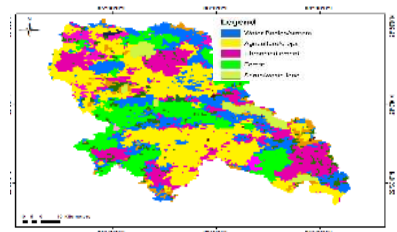

(b)

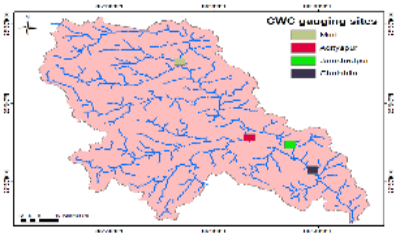

(d)
Figure 2: Input parameters of SWAT Model for upper watershed of River Subarnarekha, (a) Digital Elevation Model (DEM), (b) Land use, (c) Soil map, (d) CWC gauging site

\subsection{SWAT simulation}

Hydrologic modeling of upper watershed of river Subarnarekha was carried out using the ArcSWAT. The modelling uses the elevation profile, soil maps, soil hydrologic characteristics, land use information. These data sets were projected to the same coordinate system of zone 45 in Universal Transverse Mercator (UTM 45N). In this research, sub-basin outlets were added at Muri, Adityapur, Chandil and Jamshedpur where river gauging stations are available. Automatic delineation of the river basin was done by using DEM as input and the final outflow point of the river basin as the final pour/drainage point. Finally, the basin was sub-divided into 10 subbasins with their corresponding longest flow paths.

\subsection{SWAT model calibration and validation}

A good model calibration and validation should involve multiple evaluation techniques [32]. Calibration involves the adjustments of model parameter so that the performance and result of the model match with the observed rates in the field [33]. It is applied to the model to reduce the forecast uncertainty for a given set of selected conditions. The simulation by SWAT is based on more than 39 parameters that have to be calibrated and adjusted according the standard values [34]. Thus, the calibration process becomes complex and computationally extensive. Hence, parameter reduction is performed to filter the less influential one before the calibration process. The SWAT model was built for the period 19952005 . In the calibration process, the discharge data taken over time (timeseries) from 2001-2005 from CWC hydrological observatory site, Muri (Ranchi) was used for calibration. The first two years (2001-02) of the modelling period were reserved for "model warm-up." The next and final step is validation. The time series of monthly stream flow discharge data from 2013-2017 is used for validation process, keeping the first two year (2013-14) as warm-up period. It involves running a model using parameters that were determined during the calibration process and comparing the predictions to observed data not used in the calibration [6].

\subsection{SWAT model performance evaluation}

In this study three commonly used goodness-of-fit test is applied to estimate the model efficiency. They are coefficient of determination $\left(\mathrm{R}^{2}\right)$, Nash and Sutcliffe Efficiency (NSE) and the percent bias (PBIAS) Both the $\mathrm{R}^{2}$ and NSE ranges from 0 to 1 with higher value indicating good agreement between the model and the observation [35-37]. The PBIAS measures the tendency of the simulated flows to be larger or smaller than their observed counterparts. The optimal value is 0.0 , positive values indicate a tendency to overestimation and negative values indicate a tendency to underestimation.

The $\mathrm{R}^{2}$ and the NSE value of model calibration and validation show a good agreement between simulated and observed values (Table 1, Figure 3a \& $3 \mathrm{~b}$ ). Thus, It may be concluded that the SWAT model is well calibrated and validated for the UWRS. This can be used further for climate change impact assessment studies.
Table 1: Statistical output of model performance based on model calibration and model validation

\begin{tabular}{|l|l|}
\hline Statistical Index & $\begin{array}{l}\text { CWC site- Muri } \\
\text { (Calibration/Validation) }\end{array}$ \\
\hline NSE (Nash-Sutcliff Efficiency) & $0.81 / 0.83$ \\
\hline $\begin{array}{l}\text { Goodness of fit }\left(\mathrm{R}^{2}\right) \text { (coefficient of } \\
\text { determination) }\end{array}$ & $0.70 / 0.87$ \\
\hline PBIAS & $-12 /-11$ \\
\hline
\end{tabular}

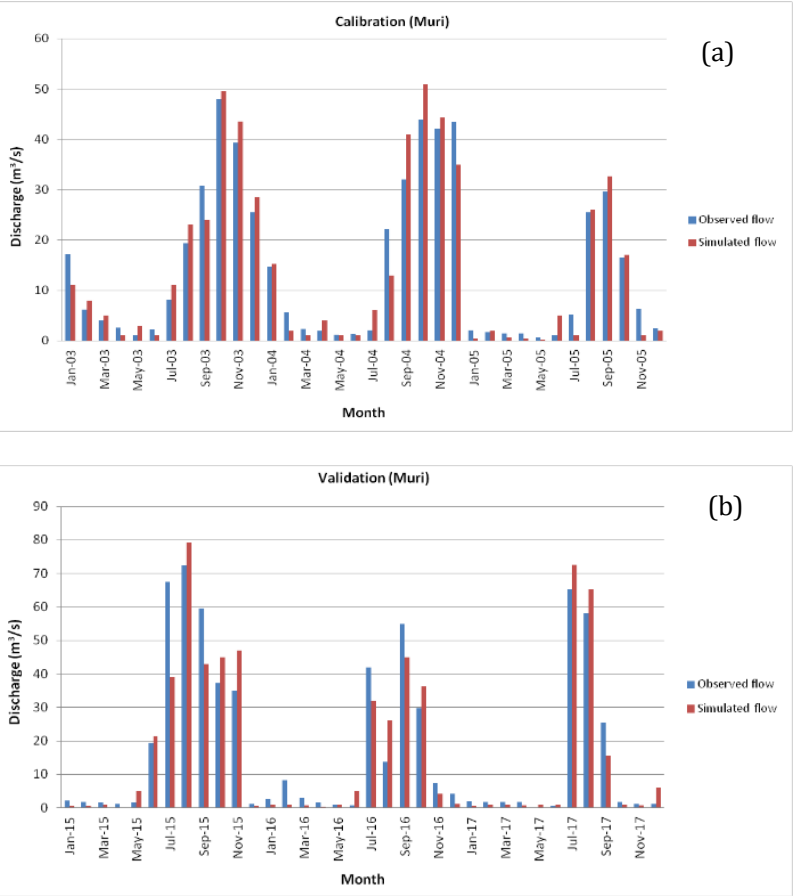

Figure 3: (a) Comparison between simulated and observed discharge for the calibration period, (b) Comparison between simulated and observed discharge for the validation period

\subsection{Sensitivity analysis}

The response of different parameters was identified through sensitivity analysis. It is necessary to identify key parameters required for the calibration process. In this study, two approaches were used for sensitivity analysis. The first approach is through automatic procedure and the second is manual approach. For automatic approach, the Latin Hypercube (LH) One-factor-At-a-Time (OAT) was used Sensitivity analysis helps in determining the rate of change in the model output with respect to the changes in model inputs parameters $[23,38]$. This is an important step, which is done prior to the calibration process. Thirteen hydrological parameters were considered for the sensitivity analysis. It is found that for UWRS curve number is the most sensitive parameter. It is followed by groundwater delay, soil evaporation compensation factor, threshold depth of water in the shallow aquifer, channel effective hydraulic conductivity, groundwater revap coefficient, soil available water capacity, base flow alpha factor, hydraulic conductivity, surface runoff lag time, deep aquifer percolation fraction. These above-mentioned thirteen parameters were found most sensitive towards generating discharge.

\section{RESULTS AND DISCUSSIONS}

The analysis of the PRECIS simulated average precipitation data for baseline (1980-2005) and SWAT model projection for the future period, Near Century (2011-2040, or 2020s), Mid Century (2041-2070, or 2050s), and End Century (2071-2098, or 2080s) is presented below.

\subsection{Precipitation projection for upper watershed of River} Subarnarekha

In the catchment, the pattern of precipitation is a dominating factor, which influences majority of hydrological parameters. The PRECIS rainfall for the projections were extracted and analyzed against the measured baseline (1980-2005) mean monthly values. Figure 4 shows a column graph of baseline and projection scenarios for Near Century (NC), Mid Centaury (MC) and End Centaury (EC). 


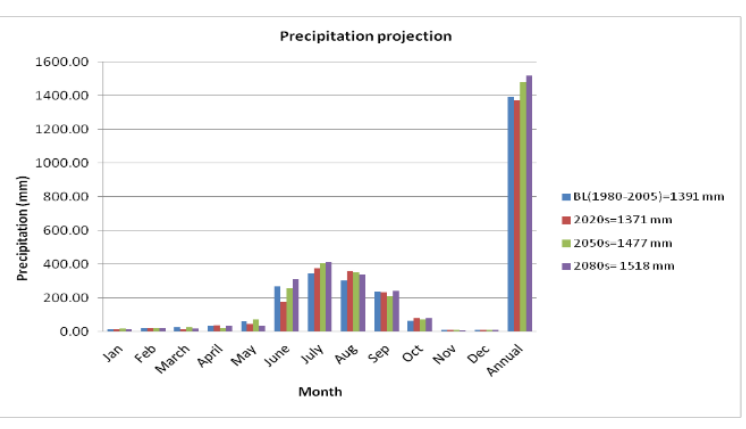

Figure 4: Precipitation projection (Baseline -BL Vs NC, MC, EC)

The calculated value of mean annual precipitation for the baseline period of upper watershed of river Subarnarekha is $1391 \mathrm{~mm}$. For rainfall projection, it is concluded that the annual mean precipitation for the UWRS, compared to the baseline will slightly decrease by $19.4 \mathrm{~mm}(1.4 \%)$ in the 2020s (NC), increase by $86.2 \mathrm{~mm}(6.2 \%)$ in the 2050s (MC), and further increase by $126 \mathrm{~mm}$ (9.1\%) in the 2080s (EC) (Figure 5).

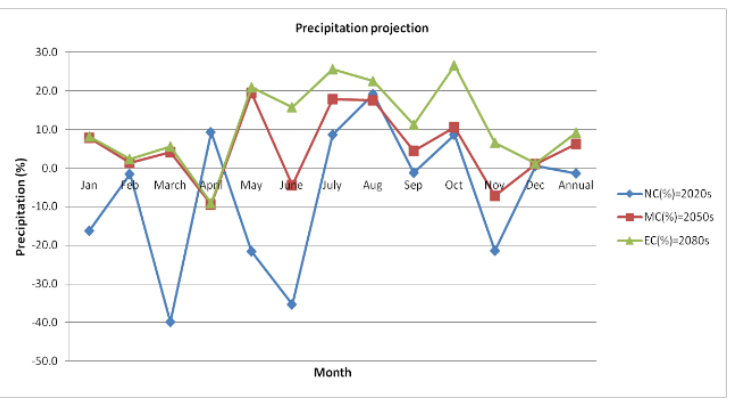

Figure 5: Percentage change in precipitation (Baseline (BL) Vs NC, MC, EC)

The spatial distribution of rainfall for baseline is represented in figure 6 . The projected trend of precipitation in the upper watershed of River Subarnarekha is not uniform. The 2020s (NC) projection is showing overall decreasing trend. The month of June is showing a decrease in precipitation of $35 \%$ from the baseline period (Figure 7). Since June is the arrival of south-west monsoon in this region, so a decrease of rainfall would severely affect the sowing of kharif season crops. However, it could also be ascertained that decrease in precipitation in the month of June for NC could be due to delay in onset of monsoon due to climate change. Narsimlu et al. (2013) have also reported this phenomenon of late arrival of South-West monsoon. The 2050s (MC) and 2080s (EC) projection is showing an increasing trend of precipitation $86.2 \mathrm{~mm}$ and $126 \mathrm{~mm}$ respectively in comparison to baseline.

For MC, the rainfall is projected to increase in northern and southern part of the watershed (Figure 8). While, for EC the entire northern and central part will experience higher rainfall (Figure 9). However, the sufficient amount of rainfall will be beneficial for the crops (availability of adequate water storage facilities) but a high intensity, continuous and widespread rainfall would increase the flood risk. Since the upper watershed of River Subarnarekha consists of undulating landforms, the excessive rainfall will affect the morphology of agricultural field. Intense rainfall will trigger the surface runoff, which may lead to destruction of terrace of agricultural field. Intense surface runoff will trigger soil erosion. In the month of October, there is increase in precipitation for MC and EC. This increase will affect the standing crop of Kharif season.

It is evident that the amount of precipitation is significantly high during the monsoon season as compared to the rest of the months. Hence, if there is a small change in water balance components in monsoon season, it reflects and represents a big change in the scale of water balance components. Any big percentage change in rest of the season reflects a minimal change in amount of precipitation. In addition, even small variation in precipitation during the monsoon period can potentially have a high influence on surface runoff, because in the monsoon period, the soil moisture is close to field capacity. The high field capacity is critical soil moisture characteristic which strongly influence the partitioning of water into infiltration, lateral flow or surface runoff. The non-monsoon season carry low soil moisture and therefore changes in rainfall do not affect runoff significantly. These precipitation results of PRECIS scenario for the upper watershed of River Subarnarekha are in conformity with other researchers $[39,40]$.

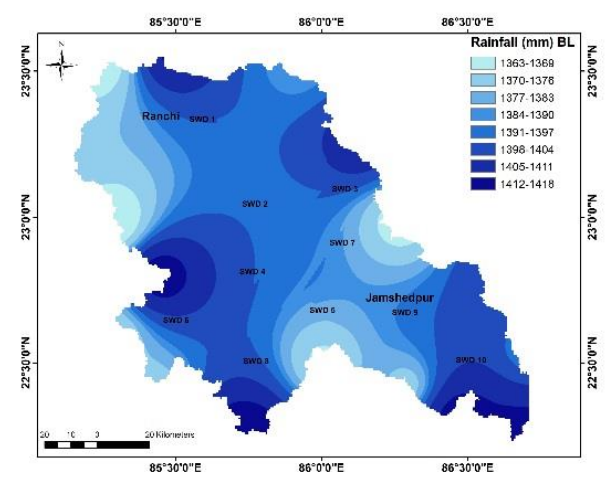

Figure 6: Baseline precipitation (1980-2005)

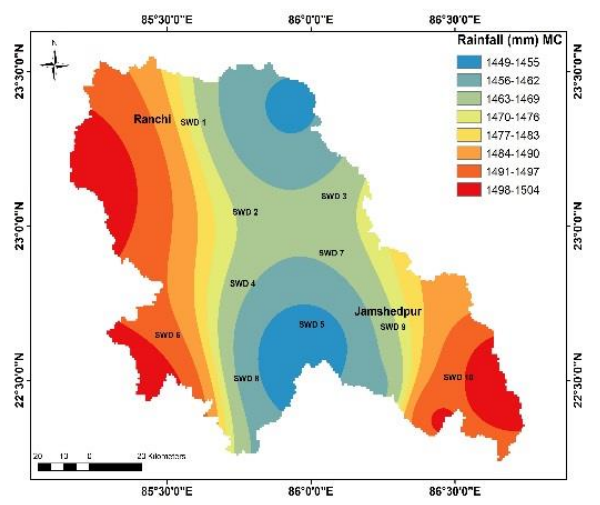

Figure 7: Precipitation projection for (Mid Century) (2041-2070)

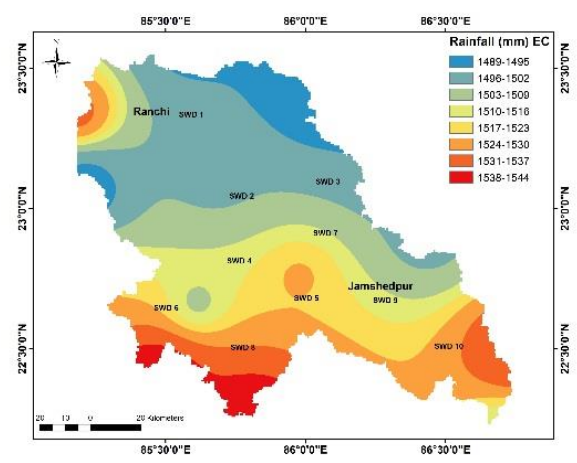

Figure 8: Precipitation projection (End Century) (2071-2098)

The results of precipitation projection clearly indicate that it would increase in MC and EC. Thus, it is concluded that the precipitation of UWRS is a dominant factor, which could affect the climate of the region. However, a host of interacting factors (wind speed, atmospheric humidity, and solar radiation) influences the climate of any particular place, the pattern of water flows and water levels of the watershed could be affected by precipitation and temperature. Thus, climate change is expected to alter hydrological regimes of UWRS.

\subsection{Impact of climate change on water balance components}

The impact of climate change on water balance components in terms of surface runoff, was analysed. It is evident to note that the water balance components are highly dictated by the weather conditions influenced by precipitation and temperature. The spatial distributions of surface runoff have also been analyzed for the BL, NC, MC and EC scenarios.

\subsubsection{Surface runoff ( $\mathrm{mm}$ )}

The intensity of surface runoff depends upon precipitation, topography, soil characteristics and land use. As per PRECIS scenario, the annual average surface runoff for the watershed is $347 \mathrm{~mm}$. The projection results indicate that the $\mathrm{NC}$ scenario of surface runoff shows a decreasing trend as compared to the baseline. For the 2020s, surface runoff shows an average annual decrease by $18.4 \%$. For the $2050 \mathrm{~s} \mathrm{(MC)} \mathrm{and} \mathrm{2080s} \mathrm{(EC),}$ there is an average annual increase by $11.8 \%$ and $38.2 \%$ respectively (Figure 10). The spatial distribution of surface runoff for baseline is represented in figure 11. Since the surface runoff is a function of 
precipitation, the results of surface runoff in upper watershed of River Subarnarekha follow the same trend of rainfall projection. A low rainfall in 2020s (NC) is transcribed into low surface runoff (Figure 12). Projection results also suggest that the anticipated surface runoff is expected to increase over central and northern part of the watershed in 2050s (MC) and 2080s (EC) respectively (Figure 13; Figure 14).

The Subarnarekha is a spring-fed river, so the hydrology of the basin is influenced by rainfall, which is affecting the surface runoff. Projected changes in precipitation are expected to change the magnitude and seasonality of runoff. The high value of surface runoff is associated with higher output of sediments load. Higher sediments load in any catchment put a significant hindrance with water resources projects and planning for dam, which store water for irrigation purpose. An increasing runoff will lead to higher flood risks for the catchment. Runoff brings sediments and silt, which are continuously deposited, in the downstream dams. This reduces the total water storage capacity. Thus, during high precipitation and subsequently high runoff will create a situation to release excessive stored water. This will further create risk of flood downstream. Thus, it may be noted that the surface runoff proportionally contributes to discharge in flood periods. Changes in the intensity of surface runoff could have significant implications for the management of floods, other high flows, and storable water. It certainly calls for a further analysis and necessary action in order to assess the magnitude of flood risk. The flood increases the volume of water and discharge of excess water will result in loss of precious resource.

Therefore, if the water is not stored in the monsoon season, it will affect the soil moisture capacity as the temperature trend is also projected to increase in future. The reduction in soil moisture will influence the agricultural activities and vegetation. The increase in surface runoff flows along the ground can pick up soil contaminants such as pesticides or fertilizers that become discharge or overland flow. The increase in anticipated urbanization will increases surface runoff, as it will create more impervious surfaces such as pavement and buildings, which will not allow the percolation of water down through the soil to the aquifer. At the same time, the increased runoff will reduces groundwater recharge, thus lowering the water table and making conditions of droughts more frequent and intense. This will affect farmers and other marginal cultivators who depend on water for livelihood. Various other studies conducted using SWAT model have also reported a similar trend of surface runoff in India [40, 41]. Where surface runoff is projected to decrease (NC) in relative to baseline conditions, additional challenges for meeting water storage and delivery needs can be anticipated. Catchment area treatment is required to counterbalance low water availability like, bunding, plantation will arrest the excessive runoff that could reduce the extent of sediment load.



Figure 9: Percentage change in surface runoff (NC,MC,EC)

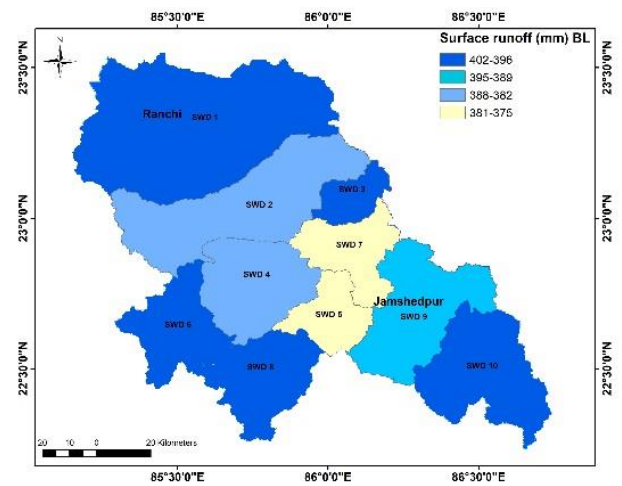

Figure 10: Base line surface run off (1980-2005)



Figure 11: Surface run off projection (Near Century) (2011-2040)



Figure 12: Surface run off projection (Mid Century) (2041-2070)

\section{CONCLUSIONS}

Upper watershed of River Subarnarekha in the State of Jharkhand, India, faces reduction of water flow during the non-monsoon periods in recent past. It has become necessary to analyze the reasons for the reduction of river flow with the help of hydrological models. Based on the SWAT model simulation and future projection of precipitation the impact on the surface runoff on the upper watershed of River Subarnarekha, the following specific conclusions are drawn:

The precipitation pattern of the projected climate is clearly influencing the water balance components in the upper watershed of River Subarnarekha. The historical trend shows a decreasing trend of precipitation, while for MC and EC the simulated results shows increasing trend of precipitation. The simulation result indicates the increase in surface runoff for $\mathrm{MC}$ and EC with increasing precipitation. A high increase in surface runoff is also expected which will elevate the risk of floods in low-lying areas in the downstream. The flood risk is more in this region due to the undulating terrain as this region is dominated by the plateau. The uncertainties of anticipated changes in precipitation pattern are translated into the simulated changes of surface runoff.

The increase in surface runoff and discharge due to increased precipitation needs to be addressed to minimize the loss of precious water. Thus, it is necessary to consider the scientific strategies and additional facilities to increase the water storage capacity of the landscape. Rainwater harvesting should be made compulsory for every household irrespective of rural or urban areas. Traditional concepts of water conservation together with scientific approach should be use to solve the problem of water crisis. Technical facilities like artificial reservoirs, infiltration sites, and check dams construction should be given utmost priority. Since the projection for NC indicates a decrease in rainfall. Hence, the water storage facilities will help in irrigation during the water stress.

The increase in surface runoff will increase the flood risks in low-lying areas in the downstream. Since the terrain is undulating, a more intensity rainfall could bring large volume of water, which has a tendency to destroy the riverbanks. The agricultural fields adjoining the riverbanks could also be affected. To counterbalance the flood risk, appropriate flood management strategies should be adopted. To start with, identification of areas having sharp meandering of river channels should be done. The construction of stone embankments on riverside will help in reduction of impact of floodwater. Wetlands are natural absorbers of storm water. Creation of more wetland and restoration of damaged wetlands should be the priority. The removal of anthropogenic encroachment on the river 
flood plain and upstream aforestation will also help in mitigation of flood. It is also advised to conduct more detailed rainfall-runoff analyses with higher temporal resolution in order to assess the future scenario of potential increase in flood. Flood forecasting model integrated with hydrological modeling could help in identification of flood prone areas.

Studies need to be conducted in a site-specific manner and appropriate mitigation measures need to be undertaken for controlling future wastage of water considering the increasing rainfall pattern and stream flow. The scientists, engineers and administrators working in this field must be updated with the latest innovations in technologies and the predictions should be incorporated into the framework of developmental policy. This will help to execute and plan action towards water conservation to mitigate the ill effects of climate change.

\section{REFERENCES}

[1] Bhadwal, S. 2003. In: Venema, H. (Ed.), Coping with Global Change: Vulnerability and Adaptation in Indian Agriculture. Teri Report. IG Printers, New Delhi.

[2] Alfieri, S.M., Riccardi, M., Menenti, M. 2019. Adaptability of global olive cultivars to water availability under future Mediterranean climate. Mitigation and Adaptation Strategies for Global Change, 24 (3), 435-466.

[3] Loucks, P., Beek, E. 2017. Water Resource Systems Planning and Management. An Introduction to Methods, Models, and Applications. Springer, Pp. 26.

[4] Mishra, A., Kar, S., Singh, V.P. 2007. Prioritizing structural management by quantifying the effect of land use and land cover on watershed runoff and sediment yield.Water Resour Manage, 21, 1899-1913.

[5] IPCC. 2007. The Physical Science Basis-Summary for Policymakers. Contribution of WG1 to the Fourth Assessment Report of the Intergovernmental Panel on Climate Change. http://www.ipcc.ch/ipccreports/ar4-wg1.htm

[6] Arnold, J.G., Srinisvan, R., Muttiah, R.S., Williams, J.R. 1998. Large area hydrologic modeling and assessment. Part I: model development. J. Am. Water Resour. Assoc., 34 (1), 73-89.

[7] Srinivasan, R., Ramanarayanan, T.S., Arnold, J.G., Bednarz, S.T. 1998. Large area hydrologic modeling and assessment part II: model application. J Am Water Resour Assoc., 34 (1), 91-101.

[8] Izydorczyk, K. 2019. The ecohydrological approach, SWAT modelling, and multi-stakeholder engagement - A system solution to diffuse pollution in the Pilica basin, Poland. Journal of Environmental Management, 248. https://doi.org/10.1016/j.jenvman.2019.109329

[9] Abbaspour, K.C. 2007. User Manual for SWAT-CUP, SWAT Calibration and Uncertainty Analysis Programs. Swiss Federal Institute of Aquatic Science and Technology, Eawag, Du" bendorf Switzerland http://www.eawag.ch/organisation/abteilungen/siam/

software/swat/index_EN

[10] Qiu, J. 2019. Impacts of climate change on watershed systems and potential adaptation through BMPs in a drinking water source area. Journal of Hydrology, 573, 123-135. https://doi.org/10.1016/j.jhydrol.2019.03.074

[11] McGrawa, D. 2019. Precipitation frequency analyses based on radar estimates: An evaluation over the contiguous United States. Journal of Hydrology, 573, 299-310. https://doi.org/10.1016/j.jhydrol.2019.03.032

[12] Saha., P.P., Zeleke, K., Hafeez, M. 2014. Streamflow modeling in a fluctuant climate using SWAT: Yass River catchment in south eastern Australia. Environ. Earth Sci., 71, 5241-5254.

[13] Kim, J.T., Choo, C.O., Kim, M.I., Jeong, G.C. 2017. Validity evaluation of a groundwater dam in Oshipcheon River, eastern Korea using a SWATMODFLOW model. Environ. Earth Sci., 76, 769. https://doi.org/10.1007/s12665-017-7085-8

[14] Ministry of Environment Forests. 2012. India's Second National Communication to the United Nations Framework Convention on Climate Change. Ministry of Environment \& Forests Government of India.

[15] India Meterological Department. 2012. Annual Climate Summary. National Climate Centre, Pune. Pp. 75.
[16] Goswami, B.N., Venugopal, V., Sengupta, D., Madhusoodanan, M.S. Xavier, P.K. 2006 Increasing trend of Extreme Rain Events over India in a Warming Environment. Current Science, 314, 1442-1445.

[17] Joshi, S., Kumar, K., Joshi, V., Pande, B. 2014. Rainfall varibility and indices of extreme rainfall analysis and precipitation study for teo stations over Central Himalaya, India. Natural Hazards, Springer, 361-374.

[18] Turner, A.G., Annamalai, H. 2012. Climate change and the South Asian summer monsoon. Nature Climate change, 2, 587-595.

[19] Rupa, K., Sahai, A.K., Kumar, K.K., Patwardhan, S.K., Mishra, P.K., Revadkar, J.V., Kamala, K., Pant, G.B. 2006. High-resolution climate change scenario for India for the 21st century. Current Science, 90, 334-345.

[20] Gupta, D.B., Mitra, S. 2004. Sustaining Subarnarekha river basin. International Journal of Water Resources Development, 20 (3), 431-444.

[21] Machado, F., Mine, M., Kaviski, E., Fill, H. 2011. Monthly rainfallrunoff modeling using artificial neural networks. Hydrol. Sci. J., 56, $349-$ 361. 10(1080/02626667), 559949

[22] Beasley, D.B., Huggins, L.F., Monke, E.J. 1980. ANSWERS: a model for watershed planning. Trans. ASAE 23 (4), 938-944.

[23] Chen, J.Y., Adams, B.J. 2006. Integration of artificial neural networks with conceptual models in rainfall-runoff modeling. J. Hydrol., 318, 232249.

[24] Fontaine, T.A., Cruickshank, T.S., Arnold, J.G., Hotchkiss, R.H. 2002. Development of a snowfall-snowmelt routine for mountainous terrain for the Soil Water Assessment Tool (SWAT). J. Hydrol., 262, 209-223.

[25] Rabus, B., Michael, E., Achim, H., Richard, B. 2003. The shuttle radar topography mission - a new class of digital elevation models acquired by space borne radar. ISPRS Journal of Photogrammetry and Remote Sensing, $57,241-262$

[26] Kumar, P., Joshi, V. 2019. A Geospatial - Statistical Approach To Alienate Priority Area Of Upper Watershed Of River Subarnarekha Using Morphometric Assessment Framework. Malaysian Journal Of Geosciences, $3(1), 01-11$.

[27] Huber, W.C., Dickinson, R.E. 1992. Storm water management model user's manual, version 4. Environmental Protection Agency, Georgia.

[28] Food and Agriculture Organisation. 2002. Digital Soil Map of the World and Derived Soil Properties. Land and Water Digital Media Series \#1 rev 1, Rome.

[29]Van Griensven, A., Meixner, T., Grunwald, S., Bishop, T., Diluzio, M., Srinivasan, R. 2006. A global sensitivity analysis tool for the parameters of multivariable catchment models. J. Hydrol., 324 (14), 10-23.

[30] Hundecha, Y., Ouarda, T.B.M.J., Bardossy, A. 2008. Regional estimation of parameters of a rainfall-runoff model at ungauged watersheds using the "spatial" structures of the parameters within a canonical physiographicclimatic space. Water Resour. Res., 44, W01427, http://dx.doi.org/10.1029/2006WR005439

[31] Central Water Commission. 1988. Water resources of India. CWC Pub. No. 30/88, CWC, New Delhi, India, Pp. 65.

[32] Legates, D.R., McCabe, G.J. 1999. Evaluating the use of "goodness-offit" measures in hydrologic and hydroclimatic model validation. Water Resources Res., 35 (1), 233-241.

[33] Moriasi, D.N., Arnold, J.G., VanLiew, M.W., Bingner, R.L.., Harmel, R.D., Veith,T.L. 2006. Model evaluation guidelines for systematic quantification of accuracy in watershed simulations. American Society of Agricultural and Biological Engineers, 50 (3), 885-900

[34] Kumar, A.R.S., Sudheer, K.P., Jain, S.K., Agarwal, P.K. 2005. Rainfallrunoff modeling using artificial neural networks: comparison of network types. Hydrol. Process., 19, 1277-1291. http:// dx.doi.org/10.1002/hyp.5581

[35] Santhi, C., Arnold, J.G., Williams, J.R., Dugas, W.A., Srinivasan, R., Hauck, L.M. 2001. Validation of the SWAT model on a large river basin with point and non-point sources. J. Am. Water Resour. Assoc., 37 (5), 1169-1188. 
[36] Nash, J.E., Sutcliffe, J.V. 1970. River flow forecasting through conceptual models, discussion of principles. J. Hydrol., 10 (3), 282-290.

[37] Coffey, M.E., Workman, S.R., Taraba, J.L., Fogle, A.W. 2004. Statistical procedures for evaluating daily and monthly hydrologic mode predictions. Transactions of the American Society of Agricultural Engineers, 47(1), 59-68.

[38] Schmalz, B., Fohrer, N. 2009. Comparing model sensitivities of different landscapes using the ecohydrological SWAT model. Adv. Geosci., 21, 91-98.
[39] Gosain, A.K., Rao, S., Basuray, D. 2006. Climate change impact assessment on hydrology of Indian river basins. Current Science, 90 (3), 346-353.

[40] Wang, L., Chen, X,W. 2008. Simulation of hydrological effects on vegetation restora-tion of degraded mountain in ecosystem with SWAT model. Journal of Mountain Science, 26 (1),71-75.

[41]Uniyal, B., Jha., M.K, Verma, A.K. 2015. Assessing Climate Change Impact on Water Balance Components of a River Basin Using SWAT Model. Water Resource Management, 29, 47-67. 